\title{
Composition and vertical distribution of free living and plant parasitic nema- todes in hop gardens in the Czech Republic
}

\author{
V. ČERMÁK ${ }^{1}$, V. GAAR ${ }^{1}$, L. HÁNĚL ${ }^{2}$, K. ŠIROKÁ ${ }^{1}$
}

\begin{abstract}
${ }^{1}$ State Phytosanitary Administration, Division of Diagnostics, Šlechtitelů 773/23, CZ-779 00 Olomouc, Czech Republic, E-mail: vaclav.cermak@srs.cz; ${ }^{2}$ Biological Centre, Academy of Science of the Czech Republic, v.v.i., Institute of Soil Biology, Na Sádkách 7, CZ-370 05 České Budějovice, Czech Republic
\end{abstract}

\begin{abstract}
Summary
Composition and vertical distribution of soil nematode communities within soil profile were investigated in eight hop gardens in Czech Republic. In total, the presence of 78 nematode genera was confirmed. Genus Drilocephalobus (Coomans \& Coomans, 1990) is new for fauna of the Czech Republic. The highest abundance of soil nematodes was found at a depth of $0-10 \mathrm{~cm}$ and declined with increasing depth of soil profile. The most dominant genus was Bitylenchus, followed by genera Acrobeloides, Ditylenchus, Chiloplacus and Cervidelus. Ten genera of plant parasitic nematodes were recorded: Bitylenchus (with prevalence of $B$. dubius), Helicotylenchus, Heterodera (with absolute prevalence of $H$. humuli), Geocenamus, Longidorella, Longidorus (only L. elongatus), Merlinius (with prevalence of $M$. brevidens), Paratylenchus and Pratylenchus. Low population densities of predators and omnivores, low values of the community indices (MI, $\Sigma \mathrm{MI}, \mathrm{SI}$, and $\mathrm{CI}$ ), and high values of NCR, EI, and PPI/MI ratio indicated disturbed nematode communities in hop gardens and bacteria-dominated decomposition pathways in the soil food web.
\end{abstract}

Keywords: Nematoda; diversity; vertical distribution; trophic groups; hop gardens

\section{Introduction}

Hops (Humulus lupulus L.) are a perennial plant, which are often grown in the same field for more than 20 years. A long growing period, large and deep root system should be connected with more stable and diverse soil biota assemblages, especially nematodes, which play an important role in nutrient cycling in soil. Nevertheless, until now, only limited information about the occurrence of nematodes in hop gardens and their vertical distribution has been available worldwide, as well as in the Czech Republic.

The studies were mainly focused on the plant parasite cyst nematode Heterodera humuli (Number, 1958; Simon, 1958; Hogger, 1988; Eppler, 1999; Mende \& McNamara, 1995). The nematode communities in hop gardens were more extensively investigated by Hay \& Pethybridge (2003) in Tasmania, by Eppler (1999) in Germany and by Malan et al. (1991) in the South Africa. Nematode vectors of plant viruses in hops were studied by Valdez et al. (1974) and McNamara and Eppler (1989). Lišková and Renčo (2007) and Renčo et al. (2010a) published detailed information on the composition and seasonal fluctuation of nematode communities in hop gardens in Slovakia.

The first record of H. humuli in Czech literature was published by Hrabě (1954), a branding of this nematode as a pest comes from Š́ly and Kříž (1961). More detailed study about the distribution of $H$. humuli in 45 Czech hop gardens was published by Šedivý (1963). H. humuli was detected at all sites with the abundances from 3 to 124 cysts per $100 \mathrm{~g}$ of soil in hop gardens younger than 20 years or 342 cysts per $100 \mathrm{~g}$ of soil in older gardens. No survey, however, evaluating the whole spectrum of nematodes in hop soil has been conducted. Therefore, the objective of this study was to describe assemblages of free living and plant parasitic nematodes and their vertical distributions in hop garden soil in Moravia and Bohemia and to evaluate the disturbance of nematode communities in these agroecosystems.

\section{Material and methods}

This study was conducted within the Tršice hop-growing area in Moravia and the Žatec hop-growing area in Northwest Bohemia. The climate of the areas is temperate with an average annual temperature of $8.0-9.5{ }^{\circ} \mathrm{C}$ (the monthly average ranges from $-1.5{ }^{\circ} \mathrm{C}$ in January to $20.1{ }^{\circ} \mathrm{C}$ in July) with annual precipitation of $450-530 \mathrm{~mm}$. During the vegetation period, average air temperatures reach $14-16^{\circ} \mathrm{C}$ and rainfalls average is $342 \mathrm{~mm}$. The soils are deep, 
Table1. The abundance of nematodes in hop gardens (ind. per $100 \mathrm{~g}$ of fresh soil in whole soil profile), mean nematode abundance $(\mathrm{n}=32)$, dominance $(\mathrm{D} \%)$

\begin{tabular}{|c|c|c|c|c|c|c|c|c|c|c|c|}
\hline Nematodes & c-p & M1 & M2 & M3 & M4 & B1 & B2 & B3 & B4 & Mean & D (\%) \\
\hline Bacterivores (B) & & 1497 & 398 & 1709 & 309 & 1342 & 2781 & 2228 & 1953 & 1527.13 & $39 \%$ \\
\hline Acrobeles & 2 & 35 & 4 & 1 & 0 & 34 & 123 & 35 & 173 & 50.63 & 1.29 \\
\hline Acrobeloides & 2 & 401 & 209 & 792 & 47 & 332 & 321 & 209 & 939 & 406.25 & 10.36 \\
\hline Acrolobus & 2 & 0 & 0 & 0 & 0 & 136 & 2 & 2 & 0 & 17.5 & 0.45 \\
\hline Alaimus & 4 & 0 & 10 & 3 & 0 & 0 & 0 & 2 & 0 & 1.88 & 0.05 \\
\hline Amphidelus & 4 & 0 & 12 & 1 & 0 & 0 & 0 & 0 & 0 & 1.63 & 0.04 \\
\hline Aulolaiums & 3 & 0 & 1 & 0 & 0 & 0 & 0 & 0 & 0 & 0.13 & 0.01 \\
\hline Bursila & 1 & 0 & 0 & 0 & 0 & 0 & 103 & 0 & 20 & 15.38 & 0.39 \\
\hline Cephalobus & 2 & 78 & 40 & 55 & 12 & 115 & 182 & 87 & 26 & 74.38 & 1.90 \\
\hline Cervidelus & 2 & 178 & 18 & 26 & 0 & 132 & 879 & 115 & 253 & 200.13 & 5.11 \\
\hline Chiloplacus & 2 & 227 & 17 & 76 & 20 & 38 & 258 & 653 & 343 & 204 & 5.20 \\
\hline Chronogaster & 3 & 0 & 8 & 0 & 0 & 0 & 0 & 0 & 0 & 1 & 0.03 \\
\hline Diploscapter & 1 & 34 & 0 & 0 & 0 & 1 & 19 & 1 & 10 & 8.13 & 0.21 \\
\hline Drilocephalobus & 2 & 0 & 0 & 0 & 0 & 45 & 48 & 27 & 0 & 15 & 0.38 \\
\hline Ereptonema & 2 & 54 & 6 & 24 & 7 & 47 & 23 & 35 & 0 & 24.5 & 0.63 \\
\hline Eucephalobus & 2 & 140 & 22 & 111 & 12 & 25 & 0 & 43 & 0 & 44.13 & 1.13 \\
\hline Eumonhystera & 1 & 19 & 8 & 17 & 0 & 24 & 276 & 88 & 17 & 56.13 & 1.43 \\
\hline Heterocephalobus & 2 & 0 & 9 & 45 & 2 & 37 & 170 & 156 & 96 & 64.38 & 1.64 \\
\hline Mesorhabditis & 1 & 103 & 5 & 93 & 0 & 0 & 0 & 11 & 0 & 26.5 & 0.68 \\
\hline Panagrolaimus & 1 & 41 & 0 & 8 & 3 & 0 & 0 & 0 & 0 & 6.5 & 0.17 \\
\hline Paraamphidelus & 4 & 0 & 6 & 0 & 0 & 2 & 0 & 13 & 0 & 2.63 & 0.07 \\
\hline Parasitorhabditis & 1 & 0 & 0 & 0 & 37 & 0 & 0 & 0 & 0 & 4.63 & 0.12 \\
\hline Pelodera & 1 & 7 & 3 & 0 & 0 & 0 & 0 & 0 & 0 & 1.25 & 0.03 \\
\hline Plectus & 2 & 0 & 1 & 6 & 12 & 2 & 7 & 22 & 1 & 6.38 & 0.16 \\
\hline Prismatolaimus & 3 & 0 & 0 & 0 & 0 & 30 & 0 & 0 & 0 & 3.75 & 0.10 \\
\hline Pristionchus & 1 & 0 & 0 & 0 & 0 & 0 & 1 & 9 & 0 & 1.25 & 0.03 \\
\hline Protorhabditis & 1 & 23 & 4 & 53 & 61 & 0 & 0 & 0 & 0 & 17.63 & 0.45 \\
\hline Rhabditis & 1 & 43 & 4 & 244 & 10 & 33 & 19 & 10 & 11 & 46.75 & 1.19 \\
\hline Rhabditis juvs., D.L. & 1 & 114 & 11 & 152 & 86 & 309 & 350 & 710 & 64 & 224.5 & 5.73 \\
\hline Rhomborhabditis & 1 & 0 & 0 & 2 & 0 & 0 & 0 & 0 & 0 & 0.25 & 0.01 \\
\hline Fungivores (F) & & 724 & 193 & 782 & 105 & 398 & 1087 & 440 & 855 & $\mathbf{5 7 3 . 0 0}$ & $14.6 \%$ \\
\hline Aphelenchoides & 2 & 333 & 51 & 115 & 47 & 232 & 210 & 129 & 332 & 181.13 & 4.62 \\
\hline Aphelenchus & 2 & 140 & 47 & 255 & 35 & 95 & 34 & 232 & 242 & 135 & 3.44 \\
\hline Deladenus & 2 & 0 & 0 & 0 & 0 & 0 & 0 & 0 & 15 & 1.86 & 0.05 \\
\hline Ditylenchus & 2 & 154 & 84 & 344 & 23 & 71 & 843 & 79 & 266 & 233 & 5.94 \\
\hline Hexatylus & 2 & 5 & 0 & 0 & 0 & 0 & 0 & 0 & 0 & 0.63 & 0.02 \\
\hline Paraphelenchus & 4 & 92 & 9 & 50 & 0 & 0 & 0 & 0 & 0 & 18.88 & 0.48 \\
\hline Safianema & 2 & 0 & 2 & 15 & 0 & 0 & 0 & 0 & 0 & 2.13 & 0.05 \\
\hline Tylencholaimellus & 4 & 0 & 0 & 2 & 0 & 0 & 0 & 0 & 0 & 0.25 & 0.01 \\
\hline Tylencholaimus & 4 & 0 & 0 & 1 & 0 & 0 & 0 & 0 & 0 & 0.13 & 0.01 \\
\hline Root-fungal feeders (RFF) & & 115 & 214 & 445 & 63 & 776 & 175 & 82 & 17 & 235.90 & $6.0 \%$ \\
\hline Basiria & 2 & 35 & 31 & 92 & 8 & 0 & 0 & 0 & 0 & 20.75 & 0.53 \\
\hline Boleodorus & 2 & 4 & 4 & 261 & 5 & 721 & 89 & 0 & 2 & 135.75 & 3.46 \\
\hline
\end{tabular}




\begin{tabular}{|c|c|c|c|c|c|c|c|c|c|c|c|}
\hline Coslenchus & 2 & 2 & 2 & 10 & 1 & 0 & 0 & 0 & 0 & 1.88 & 0.05 \\
\hline Filenchus & 2 & 70 & 172 & 62 & 49 & 53 & 86 & 51 & 11 & 69.25 & 1.77 \\
\hline Lelenchus & 2 & 0 & 0 & 1 & 0 & 0 & 0 & 0 & 0 & 0.125 & 0.01 \\
\hline Psilenchus & 2 & 0 & 0 & 2 & 0 & 0 & 0 & 0 & 0 & 0.25 & 0.01 \\
\hline Tylenchus & 2 & 4 & 5 & 17 & 0 & 2 & 0 & 31 & 4 & 7.88 & 0.20 \\
\hline Plant parasites (PP) & & 450 & 447 & 1687 & 161 & 342 & 744 & 1428 & 5975 & 1404.25 & $35.8 \%$ \\
\hline Bitylenchus & 3 & 0 & 203 & 1209 & 79 & 53 & 16 & 1049 & 5533 & 1017.25 & 25.96 \\
\hline Geocenamus & 3 & 127 & 0 & 0 & 25 & 0 & 0 & 0 & 0 & 19 & 0.48 \\
\hline Helicotylenchus & 3 & 104 & 0 & 112 & 1 & 6 & 57 & 2 & 0 & 35.25 & 0.90 \\
\hline Heterodera & 3 & 130 & 200 & 37 & 47 & 134 & 106 & 21 & 285 & 120 & 3.06 \\
\hline Longidorella & 4 & 4 & 0 & 0 & 0 & 4 & 8 & 6 & 0 & 2.75 & 0.07 \\
\hline Longidorus & 5 & 0 & 0 & 0 & 0 & 31 & 146 & 0 & 0 & 22.13 & 0.56 \\
\hline Merlinius & 3 & 0 & 27 & 56 & 7 & 106 & 409 & 337 & 153 & 136.88 & 3.49 \\
\hline Paratylenchus & 2 & 25 & 10 & 256 & 1 & 4 & 0 & 13 & 0 & 38.63 & 0.99 \\
\hline Pratylenchus & 3 & 60 & 7 & 15 & 1 & 4 & 2 & 0 & 4 & 11.63 & 0.30 \\
\hline Quinisulcus & 3 & 0 & 0 & 2 & 0 & 0 & 0 & 0 & 0 & 0.25 & 0.01 \\
\hline Predators (P) & & 33 & 12 & 17 & 18 & 13 & 4 & 79 & 100 & 34.5 & $0.9 \%$ \\
\hline Anatonchus & 4 & 0 & 0 & 1 & 1 & 0 & 0 & 0 & 0 & 0.25 & 0.01 \\
\hline Clarcus & 4 & 0 & 0 & 0 & 7 & 0 & 0 & 25 & 0 & 4 & 0.10 \\
\hline Coomansus & 4 & 0 & 0 & 0 & 5 & 1 & 0 & 0 & 0 & 0.75 & 0.02 \\
\hline Mononchus & 4 & 0 & 0 & 0 & 3 & 0 & 0 & 0 & 0 & 0.25 & 0.01 \\
\hline Mylonchulus & 4 & 0 & 2 & 6 & 2 & 11 & 2 & 50 & 0 & 9.13 & 0.23 \\
\hline Paravulvus & 5 & 0 & 0 & 6 & 0 & 0 & 0 & 0 & 0 & 0.75 & 0.02 \\
\hline Prionchulus & 4 & 0 & 0 & 0 & 0 & 1 & 0 & 2 & 2 & 0.63 & 0.02 \\
\hline Seinura & 2 & 33 & 10 & 4 & 0 & 0 & 2 & 2 & 98 & 18.63 & 0.48 \\
\hline Omnivores (O) & & 21 & 47 & 52 & 24 & 171 & 280 & 214 & 14 & 102.90 & $2.6 \%$ \\
\hline Actinolaimus & 5 & 0 & 0 & 0 & 2 & 0 & 0 & 0 & 0 & 0.25 & 0.01 \\
\hline Aporcelaimellus & 5 & 2 & 7 & 29 & 13 & 49 & 69 & 57 & 6 & 29 & 0.74 \\
\hline Aporcelaimus & 5 & 0 & 0 & 0 & 2 & 0 & 0 & 0 & 0 & 0.25 & 0.01 \\
\hline Crassolabium & 4 & 2 & 3 & 2 & 0 & 0 & 8 & 0 & 0 & 1.88 & 0.05 \\
\hline Chrisonema & 5 & 0 & 0 & 0 & 0 & 0 & 0 & 1 & 0 & 0.13 & 0.01 \\
\hline Discolaimium & 5 & 0 & 3 & 4 & 4 & 0 & 0 & 0 & 0 & 1.38 & 0.04 \\
\hline Diptherophora & 3 & 11 & 0 & 0 & 0 & 59 & 0 & 0 & 0 & 8.75 & 0.22 \\
\hline Ecumenicus & 5 & 0 & 0 & 3 & 0 & 0 & 0 & 21 & 5 & 3.63 & 0.09 \\
\hline Epidorylaimus & 4 & 0 & 1 & 0 & 0 & 0 & 0 & 0 & 0 & 0.13 & 0.01 \\
\hline Eudorylaimus & 4 & 0 & 6 & 12 & 0 & 0 & 29 & 32 & 3 & 10.25 & 0.26 \\
\hline Mesodorylaimus & 4 & 0 & 1 & 0 & 2 & 0 & 0 & 13 & 0 & 2 & 0.05 \\
\hline Microdorylaimus & 4 & 6 & 26 & 1 & 1 & 63 & 174 & 88 & 0 & 44.88 & 1.14 \\
\hline Oxidiurus & 5 & 0 & 0 & 1 & 0 & 0 & 0 & 0 & 0 & 0.13 & 0.01 \\
\hline Sectonema & 5 & 0 & 0 & 0 & 0 & 0 & 0 & 2 & 0 & 0.25 & 0.01 \\
\hline Insect parasites (IP) & & 3 & $\mathbf{0}$ & $\mathbf{0}$ & $\mathbf{0}$ & $\mathbf{0}$ & 27 & 26 & 284 & 42.5 & 1.1 \\
\hline Steinernema juvs. & 1 & 3 & 0 & 0 & 0 & 0 & 27 & 26 & 284 & 42.5 & 1.08 \\
\hline
\end{tabular}




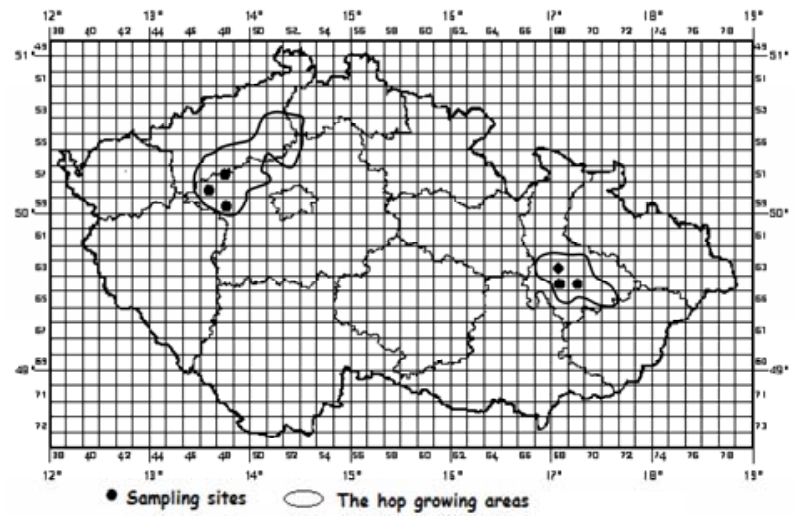

Fig. 1. Hop-growing areas and sampling sites in the Czech Republic permeable, loamy or loamy-clay, soil type Luvisol with $\mathrm{pH}$ $\left(\mathrm{H}_{2} \mathrm{O}\right) 6.5-7.5$. An exception is a shallow Marly soil with $\mathrm{pH}\left(\mathrm{H}_{2} \mathrm{O}\right) 8$ at locality B4. Except for hop plants, the soil surface was almost bare with only infrequently growing weeds (Galium aparine L., Elitrigia repens, Urtica dioica, Chenopodium album). All investigated hop gardens are designated as hop gardens with intensive production. Each year the industrial fertilizers (NPK) are applied in spring; cow manure in autumn every 3 years; liming in autumn every $3-4$ years and during each summer lacking microelements may be applied. Row cultivation is conducted in spring (soil loosening and fertilizer placement); in summer (ploughing - adding $13-15 \mathrm{~cm}$ of soil on the base of hop plants); in autumn row cultivation by ploughing to depth of $18-20 \mathrm{~cm}$ and deep ploughing of rows to the depth of 50 $-60 \mathrm{~cm}$ ones per $5-6$ years.

Localities in Moravia (M1 - M4) GPS:

M1: Senice na Hané - N49 37.192, E17 06.611 (256 m a.s.l.), M2: Domaželice - N49 25.244, E17 32.706 (231 m a.s.1.), M3: Tršice - N49.31.149, E17.23.606 (286 m a.s.l.), M4: Nelešovice - N49 31.149, E17 23.473 (278 m a.s.1.).
Localities in Bohemia (B1-B4) GPS:

B1: Lubná - N50 05.515, E13 42.920 (347m a.s.1.),

B2: Kněževes - N50 08.785, E13 37.282 (365m a.s.1.),

B3: Hořesedly - N50 09.748, E13 35.832 (389m a.s.1.)

B4: Třeboc - N50 12.385, E13 45.649 (528m a.s.1.).

Ten replicated profiles for each of 8 hop gardens (4 Moravian and 4 Bohemian; Fig. 1) were sampled to a depth of 0 $-40 \mathrm{~cm}$ in either August 2007 or in May 2008 and subdivided into layers of $0-10,10-20,20-30$ and $30-40 \mathrm{~cm}$. The soil was taken with semi-circular soil core of $5 \mathrm{~cm}$ in diameter. Extraction of nematodes was done from $100 \mathrm{~g}$ soil of bulk samples by Cobb's flotation-sieving method (Cobb, 1918). Extracted nematodes were killed and fixed by hot $3 \%$ formaldehyde and transferred to the glycerin according the De Grisse (1969) and identified under the light microscope. The Maturity Index (MI) (genus Ditylenchus included) and Plant Parasite Index (PPI) (all specimens of the trophic groups plant parasites and root-fungal feeders included) were calculated according to Bongers (1990) and $\sum$ Maturity Index ( $\left.\sum \mathrm{MI}\right)$ according to Yeates (1994). Channel Index (CI), Enrichment index (EI), and Structure Index (SI) were calculated according to Ferris et al. (2001) with weightings of nematode taxa as suggested by these authors. Nematodes were assembled to trophic groups (Table 1) according to their feeding habits as outlined by Yeates et al. (1993), and Tylenchidae were classified as root fungal feeders. Nematode Channel Ratio (NCR) and Basal Index (BI) were calculated according to Yeates (2003) and Berkelmans et al. (2003) respectively. The Shanon index (H'gen) based on natural logaritm was calculated from nematode genera (Shannon-Weaver, 1949). Ratios of trophic groups $[\mathrm{B} / \mathrm{F}, \mathrm{B} /(\mathrm{F}+\mathrm{RFF}),(\mathrm{B}+\mathrm{F}) / \mathrm{PP}$, $(\mathrm{B}+\mathrm{F}) /(\mathrm{RFF}+\mathrm{PP}),(\mathrm{O}+\mathrm{P}) /(\mathrm{B}+\mathrm{F}+\mathrm{RFF}+\mathrm{PP})]$ were calculated according to Wasilewska (2004). Statistical calculations were performed using the STATISTICA (StatSoft, 2001). ANOVA and cluster analyses of nematode genera were

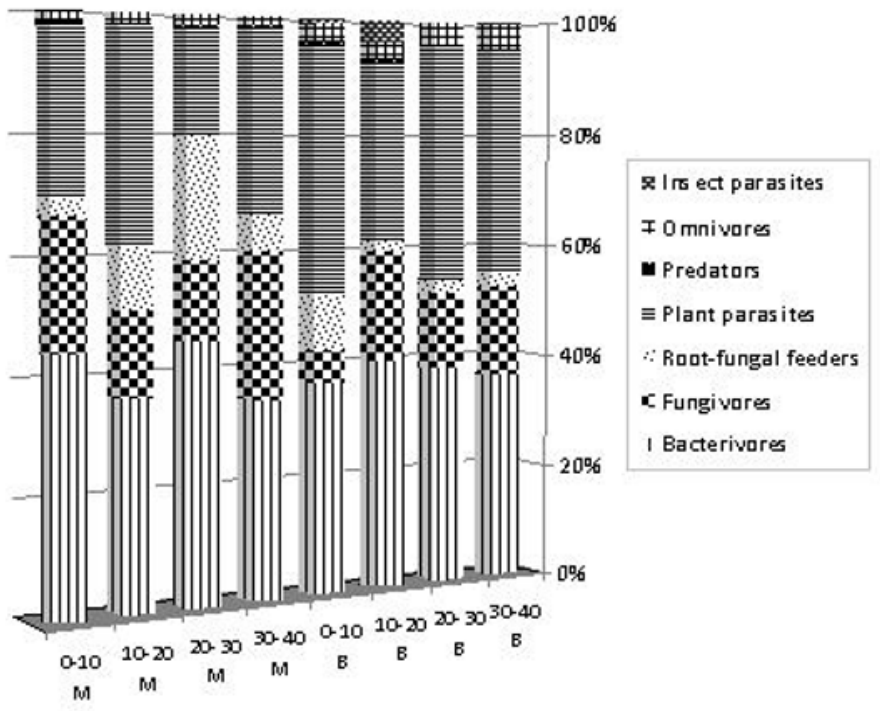

Fig. 2. Distribution of the trophic groups within soil profile, percentages of mean abundance 

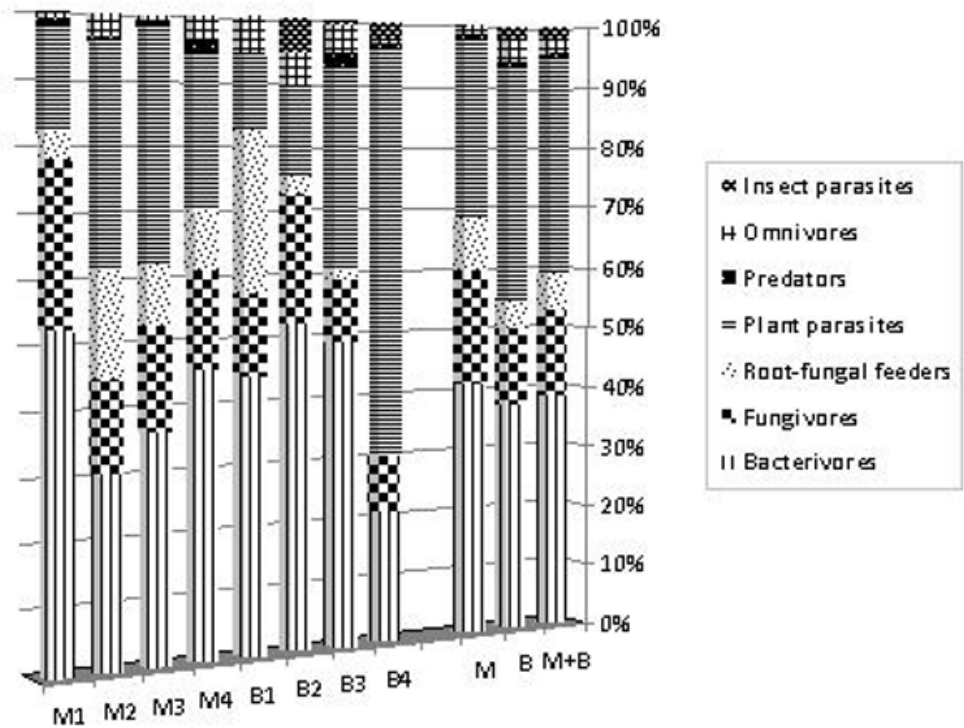

Fig. 3. Distribution of the trophic groups within localities, percentages of mean abundance

performed on $\ln (x+1)$ transformed data. The nematode genera were characterized as eudominant at $\mathrm{D}>10 \%$, dominant at $\mathrm{D}=5-10 \%$, subdominant at $\mathrm{D}=2-5 \%$, recendent $<2 \%$ (Losos et al., 1984).

\section{Results}

Composition of nematode communities in hop gardens studied

The total abundance of nematodes in hop gardens ranged from 680 to 9198 ind. per $100 \mathrm{~g}$ of fresh soil (Table 1). The most nematode individuals belonged to bacteriovores (39\%) followed by plant parasites (35.8 \%) and fungal feeders (14.6\%) (Tab. 1; Fig. 2, 3). The total mean abundance over all soil layers was significantly greater in hop gardens in Bohemia (1365 ind. per 100g of fresh soil) than in Moravia (595 ind. per $100 \mathrm{~g}$ of fresh soil) $F_{(1,30)}=8.873, p=0.006$. A trend of decreasing nematode abundance with decline of soil depth was observed (Fig. 4). Nevertheless, significant differences between the mean values of total abundance in

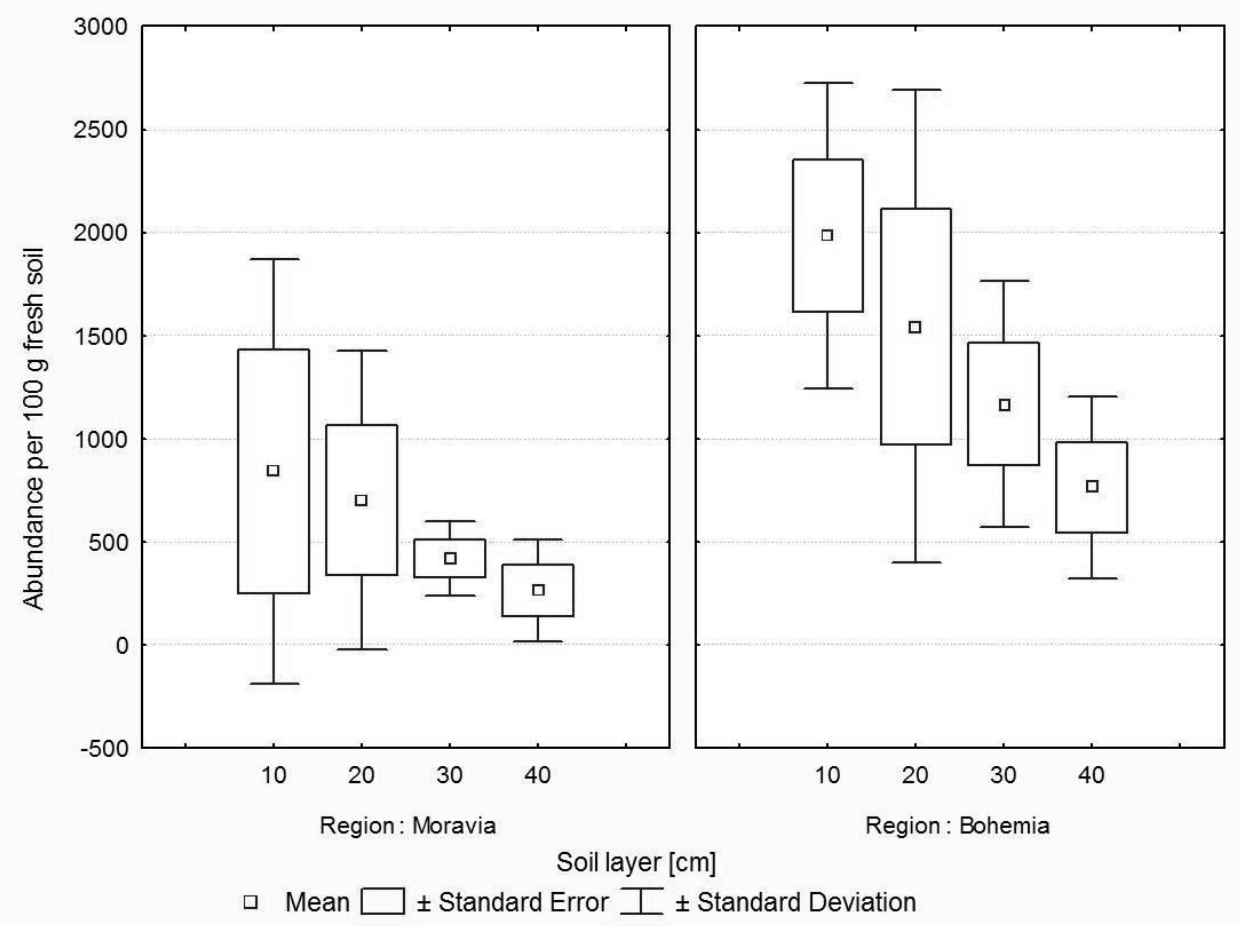

Fig. 4. Categorized box graph of nematode abundance in particular soil layer and region (numbers 10, 20,30, and 40 refer soil depth layers $0-10,10-20,20-30,30-40 \mathrm{~cm}$ ) 
Tab 2. Comunity indices of soil nematodes in hop gardens

$\mathrm{B}=$ bacterivores $; \mathrm{F}=$ fungivores; $\mathrm{RFF}=$ root-fungal feeders; $\mathrm{PP}=$ plant parasites; $\mathrm{O}=$ omnivores, $\mathrm{P}=$ predators

\begin{tabular}{lllllllll}
\hline Locality & M1 & M2 & M3 & M4 & B1 & B2 & B3 & B4 \\
\hline Numer of genera & 37 & 44 & 50 & 37 & 37 & 34 & 42 & 29 \\
$\mathrm{n}$ & 2843 & 1311 & 4692 & 680 & 3042 & 5098 & 4497 & 9198 \\
MI & 1.86 & 2.66 & 2.67 & 2.71 & 2.07 & 1.97 & 1.96 & 1.97 \\
IMI & 2.03 & 2.43 & 2.22 & 2.07 & 2.18 & 2.17 & 2.28 & 2.61 \\
PPI & 2.76 & 2.66 & 2.67 & 2.71 & 2.36 & 3.14 & 2.94 & 3.00 \\
PPI/MI & 1.49 & 1.21 & 1.44 & 1.55 & 1.14 & 1.59 & 1.50 & 1.52 \\
B/F & 2.07 & 2.08 & 2.23 & 2.94 & 3.37 & 2.56 & 5.06 & 2.28 \\
B/(F+RFF) & 1.78 & 0.98 & 1.41 & 1.84 & 1.14 & 2.20 & 4.27 & 2.24 \\
(B+F)/PP & 4.94 & 1.31 & 1.45 & 2.57 & 5.09 & 5.20 & 1.87 & 0.47 \\
(B+F)/(RFF+PP) & 5.19 & 1.79 & 1.72 & 2.96 & 7.36 & 5.43 & 1.93 & 0.47 \\
(O+P)/(B+F+RFF+PP) & 0.02 & 0.05 & 0.01 & 0.06 & 0.06 & 0.06 & 0.07 & 0.01 \\
H'gen & 3.03 & 2.75 & 2.70 & 2.93 & 2.81 & 2.81 & 2.65 & 1.67 \\
EI & 82.37 & 86.78 & 79.79 & 64.68 & 84.50 & 83.13 & 82.48 & 89.33 \\
SI & 12.91 & 65.45 & 23.17 & 41.27 & 60.99 & 48.69 & 57.37 & 16.53 \\
CI & 13.99 & 12.89 & 14.63 & 18.99 & 9.54 & 11.89 & 7.36 & 10.45 \\
BI & 17.18 & 10.59 & 19.05 & 28.30 & 12.48 & 14.54 & 14.17 & 10.45 \\
NCR & 0.64 & 0.50 & 0.59 & 0.65 & 0.53 & 0.69 & 0.81 & 0.70 \\
\hline
\end{tabular}

individual layers were not detected either for all hop gardens $(\mathrm{F}(3.28)=2.418, \mathrm{p}=0.087)$ or Moravian $(\mathrm{F}(3.12)$ $=1.178, \mathrm{p}=0.359)$ as well as Bohemian $(\mathrm{F}(3.12)=1.806$, $\mathrm{p}=0.200$ ) hop gardens. The assumption of homogeneity of variances in one-way ANOVA was not violated, and analyses performed of $\ln (\mathrm{x}+1)$ transformed abundance gave practically the same results. On the other hand oneway ANOVA, performed on $\ln (\mathrm{x}+1)$ transformed data, detected significantly different abundance of predators in individual layers $\left(F_{(3.28)}=4.415, p=0.012\right)$. Poc-hoc Fisher LSD test at $\alpha=0.05$ suggested significantly greater abundance of predators in the layers $0-10 \mathrm{~cm}$ (16.6 ind. per $100 \mathrm{~g}$ of fresh soil) and $10-20 \mathrm{~cm}(13.5)$ than in $20-$ 30 (2.5) and $30-40 \mathrm{~cm}$ (1.5).

Within investigated hop gardens, 78 nematode genera in total material of 31361 nematodes were recorded. The genus Drilocephalobus was recorded in the Czech Republic for the first time. The Bitylenchus $(26.0 \%)$ was found as eudominant genera; Acrobeloides (10.4\%), Ditylenchus (5.9\%), Chiloplacus (5.7\%), and Cervidelus (5.1\%) as dominant genera. Ten plant parasitic genera were found: Bitylenchus (with prevalence of B. dubius, Helicotylenchus, Heterodera (with absolute prevalence of $H$. humuli), Geocenamus, Longidorella, Longidorus (only $L$. elongatus), Merlinius (with prevalence of M. brevidens), Paratylenchus and Pratylenchus. The most common species from the genus Aphelenchoides were A. limberi Steiner, 1936 and $A$. bicaudatus, which are not considered to be plant parasites.

Distribution of nematodes within soil profile showed, that in the first soil depth $(0-10 \mathrm{~cm})$ the eudominant genera were Acrobeloides (21.5\%), Bitylenchus (18.8\%) in Mo- ravia region and Bitylenchus $(35.0 \%)$ in Bohemia region. The similar dominance of nematode genera was recorded in the second soil layer $(10-20 \mathrm{~cm})$ as well, where in Moravia hop gardens the Bitylenchus (20.3 \%) and Acrobeloides $(14.2 \%)$ dominated and in Bohemia hop gardens Bitylenchus $(24.0 \%)$ was eudominant genus. However, in the third soil layer investigated $(20-30 \mathrm{~cm})$ in Moravia region the different genera dominated, namely Rhabditis (13.8\%) and Filenchus $(10.1 \%)$, while in Bohemia region it was the same with eudominance of the genus Bitylenchus (34.1\%). As showed the results from the fourth investigated soil depth $(30-40 \mathrm{~cm})$ in Moravia were the most dominant Aphelenchoides (12.9\%) and Bitylenchus (10.7\%) genera, in Bohemia Bitylenchus (26.3\%) and Acrobeloides (12.2\%).

Insect parasitic nematodes were represented by only one genus (Steinernema), which was present in half of the sampling sites with the highest abundance 223 specimens per $100 \mathrm{~g}$ of soil sample (locality B4) in the layer $10-20 \mathrm{~cm}$.

Evaluation of nematode communities by ecological and diversity indices, statistical analysis

Evaluation of soil nematode communities by community indices within investigated hop gardens is presented in Table 2. Dominance of bacterivorous nematodes reflected high values of NCR, EI, and CI and higher values of ratios $\mathrm{B} / \mathrm{F}$ and $\mathrm{B} /(\mathrm{F}+\mathrm{RFF})$. The highest dominance of bacterivorous nematode in soil food web was at locality B3. The values of H'gen were relatively high except B4 locality, but this locality showed the highest value of $\Sigma \mathrm{MI}$. MI varied from 1.86 to 2.71 , whereas the values of PPI were always greater than 2.30 , resulting in high values of the PPI/MI ratio of $1.14-1.59$. Low values of SI at localities 


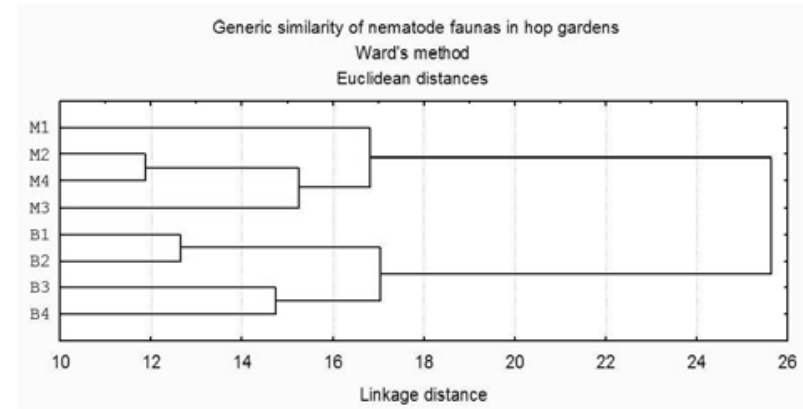

Fig. 5. Cluster analysis of $\ln (x+1)$ transformed soil nematode genera in whole soil profile of hop gardens sampled in the Czech Republic ( $\mathrm{M}=$ Moravia, $\mathrm{B}=$ Bohemia, numbers 1-4 refer to replicate sites)

$\mathrm{M} 1, \mathrm{M} 3$ and $\mathrm{B} 4$ correspond with very low values of the $(\mathrm{O}+\mathrm{P}) /(\mathrm{B}+\mathrm{F}+\mathrm{RFF}+\mathrm{PP})$ ratio. The ratios $(\mathrm{B}+\mathrm{F}) / \mathrm{PP}$ and $(\mathrm{B}+\mathrm{F}) /(\mathrm{RFF}+\mathrm{PP})$ were greater at localities $\mathrm{M} 1, \mathrm{~B} 1$ and $\mathrm{B} 2$ and the lowest at locality B4. The values of BI were the greatest at locality M4 and the lowest at M2 and B4.

Cluster analysis performed on $\ln (\mathrm{x}+1)$ transformed genera population densities in whole soil profile (Fig. 5) showed Moravian sites were clearly distinct from Bohemian sites. Position of the site M1 was influenced by the absence of Bitylenchus dubius. Cluster analysis of nematode genera based on $\ln (\mathrm{x}+1)$ transformed abundance data in individual sites and soil layers (Fig. 6) provided a similar picture of clearly distinct Bohemian and Moravian sites, except for $\mathrm{B} 1(30-40 \mathrm{~cm})$ and B3 $(30-40 \mathrm{~cm})$ in the upper cluster. The position of $\mathrm{B} 1$ and $\mathrm{B} 3$ sites on the same cluster with M2 $(0-10 \mathrm{~cm})$ is the result of low abundances of root fungal feeders and the absence of genus Steinernema.

\section{Discussion}

The soil nematode communities in the hop gardens studied are characterized by a dominance of bacterivores and plant parasites, which is consistent with the trophic composition of nematode faunas previously found in agroecosystems of the Czech Republic (Háněl, 2003) or in Poland (Wasilewska, 1979). A similar trophic structure of nematodes was also found in hop gardens in Slovakia (Lišková \& Renčo, 2007). Nevertheless, the dominant genera were different. In Slovakia, the genus Rhabditis was the most dominant bacterial feeding nematodes which were further confirmed by Renčo et al. (2010a), whereas in Moravia and Bohemia hop gardens the most dominant bacterivore was Acrobeloides. The prevalence of bacterial feeders and

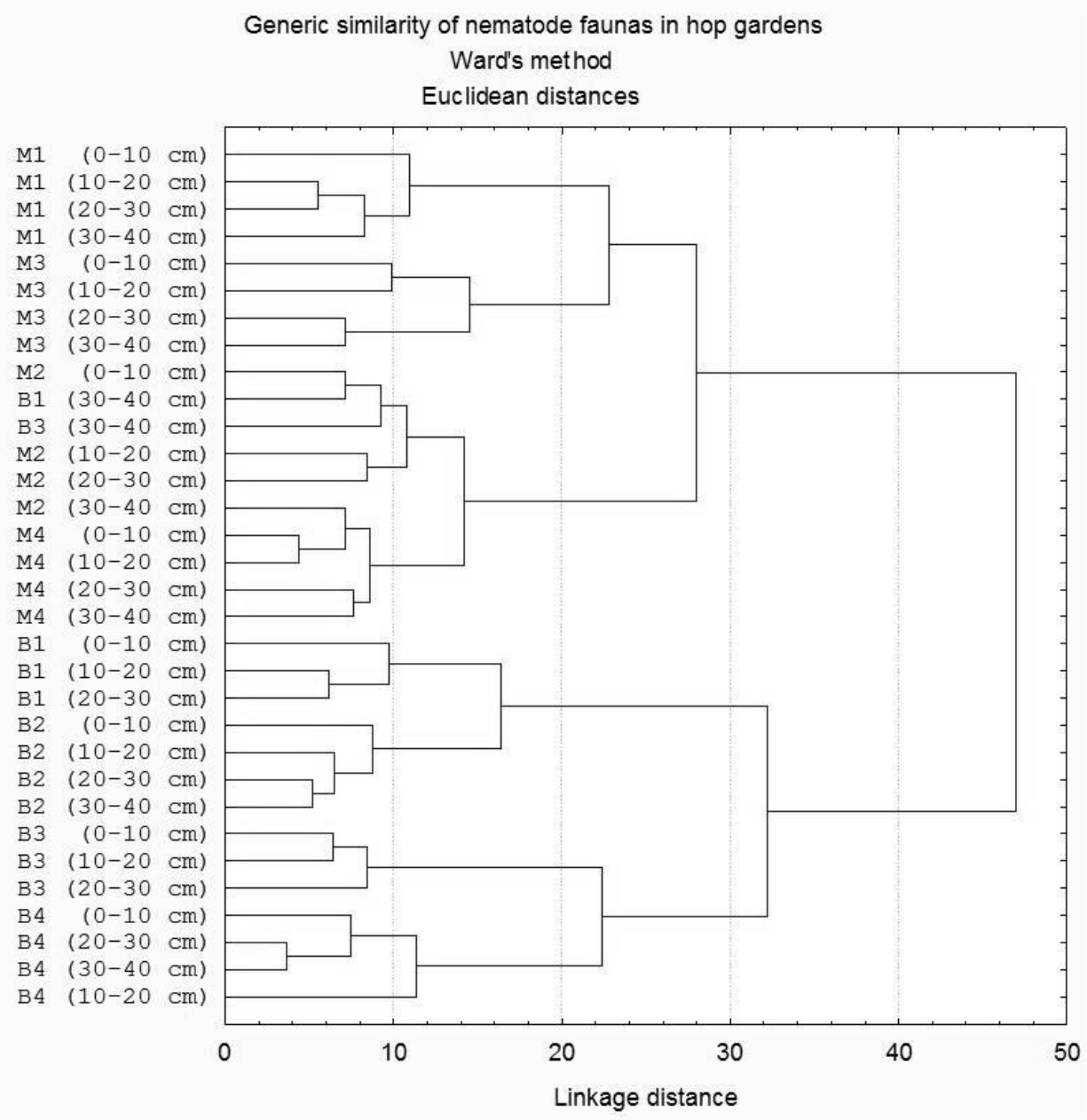

Fig. 6. Cluster analysis of nematode genera based on $\ln (x+1)$ transformed abundance data $(\mathrm{M}=$ Moravia, $\mathrm{B}=$ Bohemia, numbers $1-4$ refer to replicate sites, numbers $10-40$ refers soil depth layer in $\mathrm{cm})$ 
plant parasitic nematodes were observed in other agroecosystems as well (Bouwman \& Zwart, 1994; Renčo \& Valocká, 2002). These results correspond to a general pattern of nematode communities in agroecosystems in temperate areas. Generally, the nematode communities in agricultural soils of Central Europe are less diverse compare to those in more stable ecosystems like forests (Háněl \& Čerevková, 2010) or meadows (Háněl \& Čerevková, 2006), but always with a greater proportion of bacterivores and plant parasites (Háněl, 2010).

The prevalence of bacterivores in hop gardens studied may be caused by regular fertilization with manure per each $2-$ 3 years and with industrial fertilizers each year. This result is similar to those published by Lišková and Renčo (2007). The manner of decomposition of organic matter can be evaluated by $\mathrm{B} / \mathrm{F}$ index, which is focused on the dominant way of decomposition either by bacteria or fungi. Relatively high values of $\mathrm{B} / \mathrm{F}$ index show relatively greater participation of bacteria in the breakdown of soil organic matter. The highest value of $\mathrm{B} / \mathrm{F}$ index 5.06 was found in B3 sampling site. This deviation from other sites was the result of the high abundance of the genus Chiloplacus and Acrobeloides and the low presence of the genus Ditylenchus. On the other hand, the lack of knowledge about nematodes' biology and trophic characterization can affect the resulting values of indexes. For example, some species from genus Aphelenchoides or Ditylenchus are classified as plant parasites, but can be cultivated on fungi (Hooper \& Cowland, 1986; De Waele et al., 1997). Many species from the order Tylenchida are classified as fungal feeders or root fungal feeders only because of their short stylet (Yeates, 1986), especially from the family Tylenchidae or from the genus Ditylenchus. The species from the genus Cephalobus are generally classified as bacterivores (Yeates et al., 1993), but it was discovered that they can also be reproduced on fungi Verticillium dahliae Klebahn, or roots of clover or maize infected by fungi and on callus culture of alfalfa (Solovyeva et al., 1976).

Similar results are also seen in a group of free-living nematodes that could generally be classified as omnivores. They usually have different trophic cycles based on favourable or unfavourable living conditions, mainly on availability of sources of nutrients and their kinds. Analogically some species of the genus Aphelenchoides (Hooper \& Ibrahim, 1994) and some Ditylenchus species are classified as fungal feeders in general, but are often found inside damaged plants (Wasilewska, 1965; Brzeski, 1991). Their patogenity was not tested or only fragmentary information is known, and the species can feed under the enriched conditions on the most convenient source of nutrient, and in a nutritionally stressed environment, feed on other organisms, which they are able to attack.

The occurrence of plant parasites was generally higher in comparison to the ecosystem of hop gardens in Slovakia (Lišková \& Renčo, 2007). The nitrogen is generally regarded as a limiting factor for many herbivores, including nematodes (Mattson, 1980) and a higher $\mathrm{C}: \mathrm{N}$ ratio will reduce the number of nematodes (Renčo et al., 2007). The availability of nitrogen and phosphorus generally depends on the host plant species and the changes not occur during the succession of growth (Olff et al., 1994), and interactions with other elements of ecosystem. The changes in $\mathrm{C}: \mathrm{N}$ ratio can influence the plant parasitic nematodes. The higher $\mathrm{C}: \mathrm{N}$ ratio may be connected with a higher level of defensive compounds in plant tissues (Hartley et al., 1995), which might deter plant-feeding nematodes (Mattson, 1980; Renčo et al., 2009, 2010b). Due to the regular application of manure and fertilizers in the investigated hop gardens, the low $\mathrm{C}: \mathrm{N}$ ratio, good availability of $\mathrm{N}$ and $\mathrm{P}$, and rich root system can be expected and those can explain high abundances of "large" plant parasitic nematodes. Especially for nematode species with high nutrient and energy needs, a decrease in food quality can have a considerable effect on the population size. This effect was confirmed by Verschoor et al. (2001) during their investigation of changes in the composition of the plant-feeding nematode community in grassland after cessation of fertilizer application. Particularly, relatively large nematode genera such as Longidorus, Heterodera, Helicotylenchus and Tylenchorhynchus declined or even disappeared when the nutrient availability decreased, whereas smaller nematode taxa such as Aglenchus, Filenchus, Pratylenchus and Paratylenchus were abundant in all sites and dominated in the nutrient-poor sites.

The investigated hop gardens are characterized by a low diversity of plant parasites (only 10 genera) but with high abundances. The number of plant parasitic genera is lower in comparison with other agroecosystems studied in Czech Republic or in Slovakia. Háněl (2010) found 13 plant parasitic genera during his investigation of six fields (one cultivated and five abandoned). Six of them (Rotylenchus, Xenocriconemella, Mesocriconema, Criconema, Meloidogyne and Trichodorus) were not recorded in our investigated hop gardens. Their absence, especially of the members of family Criconematidae, which are characteristic for growth of perennial crops such as vineyards and fruit orchards (Lišková et al., 2004), and genus Meloidogyne, was probably due to the type and kind of soil. The low numbers of plant parasitic genera and species as the most frequent plant parasitic genera (Bitylenchus, Merlinius and Heterodera) are also characteristic for hop gardens of Slovak Republic (Lišková \& Renčo, 2007). Bitylenchus dubius prevailed in the group of plant parasites in the hop gardens in the Czech Republic whereas this species was less prominent in the hop gardens in Slovakia. Although the abundance of $B$. dubius varied with locality, in both regions a cluster analysis showed that the composition of whole nematode fauna in Moravian and Bohemian hop gardens is evidently different. The association of Meloidogyne spp. with hop was recorded in Tasmania (Hay \& Pethybridge, 2003) and M. hapla in USA (Maggenti, 1962), should be an alarm signal for Czech hop production because of widely spread M. hapla in the Province of Central Bohemia (Zouhar et al., 2003).

Nevertheless, the very low abundance of predators and omnivores in the hop gardens studied can be interpreted as 
a sign of negative influence of agricultural practices upon soil nematode communities (Wasilewska, 1997). The most abundant omnivores here were genera Microdorylaimus, Aporcelaimellus and Eudorylaimus. Lišková \& Renčo (2007) also found a low abundance of omnivores and plant parasites in hop gardens in Slovakia, with the exception of two species with high dominance and frequency of occurrence of Eudorylaimus juvs. and Aporcelaimellus obtusicaudatus. It seems that genera Eudorylaimus, Aporcelaimellus and Mesodorylaimus are the most common and abundant omnivores independent of type of ecosystem or climatic conditions (McSorley, 1997; Háněl 1994, 2008; Wasilewska, 2006). All of these genera belong to the superfamily Dorylaimoidea (Andrássy, 2009) and are considered to be the first colonizers in early successional stages because of their ability to feed on algae, bacteria, fungi, mosses, plant roots and microfauna (Bongers \& Ferris, 1999) and can include species that can either behave as colonizers or persisters (Háněl, 2010). For those reasons, they were probably able to survive stressful conditions in cultivated hop soil.

The genus Microdorylaimus was most abundant omnivore in our study with $\mathrm{D}=1.14 \%$. Ettema and Bongers (1993) discovered temporary increasing of abundance of genus Microdorylaimus on manured plots in contrast to untreated ones, therefore its high abundance was attributed to the organic treatment and indicated a possible relation between the abundant algae growth in the food-rich soil in summer and species abundance in the upper $15 \mathrm{~cm}$ of investigated soil profile, because of green intestine determined as algae. The water content, together with soil porosity, temperature and food webs are one of the main factors influenced the occurrence and abundance of soil nematodes (Yeates et al., 2002; Sohlenius \& Boström, 2001). Bakonyi et al. (2007) indicates the increase of dominance of this genus in dried and warmed poplar and bare soil plots compared to the control and decreasing in fescue soil plots; no significant response of genus Eudorylaimus and variable responses of genus Aporcellaimellus were detected. Moreover, the reason for the high occurrence of Microdorylaimus in dry soils without plant cover (except hop plants) can be the result of smaller body size in comparison with other two genera. The smaller body size allow them to occupy the soil food web niche (algae etc.) through the soil profile, which are for larger genera unreachable because of decreasing water content in soil, starts from larger to smaller pores due to lower tension of larger pores in comparison with smaller pores (Jandák et al., 2001). According to Griffiths et al. (2003) only a small quantity of water-filled pores in the soil is sufficient to maintain nematode activity and the densities of larger species are more affected by soil temperature and moisture changes than are those of smaller ones (Griffin et al., 1996). The ability to feed on various food sources, positive reaction to increasing food source and small body size, should be the most important features for explanation of the rich distribution of genus Microdorylaimus through the whole soil profile in our investigated hop gardens. Renčo et al. (2010a) established that decreasing abundances of the majority of omnivores and predators during the July were positively correlated with decreasing precipitation and high temperatures. Omnivores and predators have great sensitivity to disturbances (Bongers et al., 1991; Brmež et al., 2006). The high temperatures, low amount of precipitation and frequent agricultural practices (tillage and application of pesticides and fertilizers) should be the main factors that influenced the abundances of nematodes belonging to these trophic groups in the investigated hop gardens.

Within the group of plant-viruses vectors, only Longidorus elongatus was detected. This is the first official record of virus-vector nematode in hop gardens in Czech. Our finding is qualitatively very low in comparison with results from hop gardens in Germany, where McNamara and Eppler (1989) refer to 11 virus-vector nematodes species from 3 genera. Hay and Close (1992) refer species Xiphinema diversicaudatum from hop gardens in New Zealand. No one is referred from Slovakia or from Tasmania (Lišková \& Renčo, 2007; Hay \& Pethybridge, 2003). The low occurrence of virus-vector nematode species in Czech hop gardens in comparisons with Czech vineyards or fruit orchards (Erbenová, 1975; Kumari, 2006) can be explained (as in the case of Criconematidae) by the different sorts and types of soil, the low number of soil samples or nonsuitable sampling patterns for virus-vector nematodes. Hay and Close (1992) found $X$. diversicaudatum in 31 from 240 diagnosed samples collected in hop gardens from which 28 were taken at the edge of fields. The same sampling pattern referred McNamara and Eppler (1989). Hay and Close (1992) considered that the prevalence of $X$. diversicaudatum at the edges of field is due to the preference of host plants in the outer areas including the species used as shelterbelts and many herbaceous weeds and grasses (Thomas, 1970). More over both $X$. diversicaudatum and Arabic Mosaic Virus are present in the Czech Republic (Polák, 1994; Kumari et al., 2005). Therefore, further monitoring of the occurrence of virus-vector nematodes is required in the future.

Lower values of MI, $\sum \mathrm{MI}, \mathrm{H}^{\prime}$ gen, SI, CI and higher values of EI in our hop gardens investigated compared to those recored by Háněl and Čerevková (2006) in natural meadows or spruce forest (Čerevková \& Renčo, 2009) indicate poorly-regulated, disturbed ecosystems (Ferris et al., 2001). This conclusion was also supported by the results of $(\mathrm{O}+\mathrm{P}) /(\mathrm{B}+\mathrm{F}+\mathrm{RFF}+\mathrm{PP})$, which also indicate a poor health ecosystem (Wasilewska, 1997). BI values were relatively low in comparison with results of Berkelmans et al. (2003) from fields grown with annual crops, at where the high BI values indicated poor ecosystem health. The BI values for localities B4 and M2 (10.45 and 10.59 respectively) are comparable with results of Háněl (2008) for localities on colliery spoils grown with broad leaves trees with grass understorey, which suggest shift from nutrient disturbance to balanced use of nutrient resources by higher plants (Bongers et al., 1997). The higher values of (B+F)/PP and $(\mathrm{B}+\mathrm{F}) /(\mathrm{RFF}+\mathrm{PP})$ at localities $\mathrm{M} 1, \mathrm{~B} 1$ and $\mathrm{B} 2$ show a trend of slower rates of mineralization via decomposition chan- 
nel in the soil food web via plant feeders (Wasilewska, 1997) and may suggest higher content of organic compounds in that soil food web together with higher microbial biomass levels in those localities (Ferris et al., 1996). The values of PPI/MI ratio in hop gardens varied from 1.14 1.59 , which indicates habitats where higher plants started to make non-optimal use of nutrient or nutrient disturbances (Bongers et al., 1997). Similar results were found in hop gardens in Slovakia (Lišková \& Renčo, 2007) or in sugar beet or cereals fields (Renčo, 2002, 2003), while in the grass ecosystems lower values of PPI/MI ratio were found (Valocká et al., 2001; Lišková \& Čerevková, 2005). The great abundance of bacterivores, high values of NCR, high values of EI, and low values of CI could indicate relatively greater participation of bacteria in the breakdown of soil organic matter (Ferris et al., 2001), although we would instead expect a decomposition pathway more dominated by fungi and fungivores in perennial crops (Neher \& Campbell, 1994). The probability of more active bacterial based channel than the fungus based channel was also supported by higher values of $\mathrm{B} / \mathrm{F}$ and $\mathrm{B} /(\mathrm{F}+\mathrm{RFF})$, mainly at locality B3 (5.06 and 4.27 respectively). The composition of nematode in the hop gardens studied thus showed clear marks of disturbance, which could be caused by the long-term use of pesticides, regular soil loosening and ploughing. Nevertheless, there is also one other issue. A marked effect of region upon nematode faunas in agroecosystems shown in cluster analysis has been confirmed by Háněl (2003). The nematode faunas in grasslands on the western and eastern slopes of White Carpathians exhibited clearly detectable differences (Háněl \& Čerevková, 2006), too. Because of a great variety of geomorphological units in the Czech Republic, and in a broader sense in the Central Europe, the effect of region upon composition of local nematode faunas (including plant parasites occurrence in agroecosystems) should be taken into consideration when evaluating their disturbance by human activities.

The vertical distribution of nematodes in soil shows two main patterns: 1) the majority of nematodes are concentrated in the upper soil layer of $0-10 \mathrm{~cm}$ (Yeates, 1980; Háněl, 1997), and 2) nematodes are distributed evenly within the soil profile (Š́ly, 1973; Castillo et al., 1985). Usually $70-80 \%$ of nematode individuals in various ecosystems occur at a depth of $0-30 \mathrm{~cm}$ (Ou et al., 2005, Sohlenius \& Sandor, 1987; McSorley \& Dickson, 1990). Our data instead reflected a model of gradually decreasing nematode abundance, in which values in individual soil layers and regions overlapped. Nevertheless, it must be taken into consideration that the vertical distribution of nematodes is seasonally changeable (Pen-Mouratov et al., 2003, Renčo et al., 2010a) and our study was for technical reasons, carried out as a single survey of localities over two different periods. Other factors that could contribute to insignificant differences in total nematode densities between soil layers are soil cultivation by ploughing, different trophic groups and genera in soil profile that can respond to tillage differently (López-Fando \& Bello, 1995) and the interaction with the application of agro-chemicals
(Fiskus \& Neher, 2002). Elucidation of the vertical distribution of nematodes in hop gardens, with special emphasis on the distribution of plant parasites and virus vectors, will therefore need more detailed studies.

\section{Acknowledgements}

We would like to thank the Division of Diagnostics of SPA for its support; Petr Born and Ivo Klapal for planning and facilitation of sampling; and anonymous reviewers for their helpful comments. The study was carried out as a part of the IRP ISB BC AS CR AV0Z60660521 (L. Háněl).

\section{References}

ANDRÁSSY, I. (2009): Free-living nematodes of Hungary III (Nematoda errantia). Budapest, Hungarian Natural History Museum and Systematic Zoology Research Group of the Hungarian Academy of Sciences: 608 pp.

BAKONYI, G., PÉter, N., KovÁcs-LÁNG, E., KovÁcs, E., BARABÁs, S., RÉPASI, V., SERES, A. (2007): Soil nematode community structure as affected by temperature and moisture in a temperature semiarid shrubland. Appl. Soil Ecol., 37: 31 - 40. DOI: 10.1016/j.apsoil.2007.03.008

Berkelmans, R., Ferris, H., Tenuta, M., van BRuggen, A. H. C. (2003): Effects of long-term crop management on nematode trophic levels other than plant feeders disappear after 1 year of disruptive soil management. Appl. Soil Ecol. 23: $223-235$

BONGERS, T. (1990): The maturity index: an ecological measure of environmental disturbance based on nematode species composition. Oecologia 83: $14-19$

Bongers, T., Ferris, H. (1999): Nematode community structure as a bioindicator in environmental monitoring. Trends Ecol. Evolut., 14: 224 - 228

Bongers, T., Alkemande, R., Yeates, G. W. (1991): Interpretation of disturbance-induced maturity decrease in marine nematode assamblages by means of the maturity index. Mar. Ekol. Prog. Ser. 76: 135 - 142

BOnGers, T., VAB DER Meulen, H., Korthals, G. (1997): Inverse relationship between the nematode maturity index and plant parasite index under enriched nutrient conditions. Appl. Soil Ecol. 6: 195 - 199

BOUWMAn, L. A., ZWART, K. B. (1994): The ecology of bacterivorous protozoans and nematodes in arable soil. Agric. Ecosyst. Environ., 51: 145 - 160

BRMEŽ, M., IVEZIČ, M., RASPUDIČ, E. (2006): Effect of mechanical disturbances on nematode communities in arable land. Helminthologia, 43: 117 - 121. DOI: 10.2478/s11687-006-0022-0

BRZESKI, M. W. (1991): Review of the genus Ditylenchus Filipjev, 1936 (Nematoda: Anguinidae). Revue Nématol. 14 (1): $9-59$

Castillo P., Peña Santiago R., Jiménez Millán F. (1985): Modelos de distribución vertical de las especies de nematodos en un biotopo natural. I. Bol. Serv. Plagas, 11: $155-162$

ČEREVKovÁ, A. (2006): Nematode communities in three 
type sof grassland in the Slovak Republic. Helminthologia, 43: 171 - 176. DOI: 10.2478/s11687-006-0032-y

ČEREVKOVÁ, A., RENČO, M. (2009) Soil nematode community changes associated with windfall and wildfire in forest soil at the High Tatras National Park, Slovak Republic. Helminthologia, 46: 123 - 130. DOI: 10.2478/s11687-009-0024-9

De Waele, D., Venter, C., McDonald, A. H. (1997): The peanut pod nematode, Ditylenchus africanus. Nematology Circular, 218: $1-6$

Eppler, A. (1999): Die Fauna des Hopfens. Proceedings 51st international symposium on crop protection, Gent, Belgium. Universiteit Gent, 64: 133 - 147

ERBENOVÁ, M. (1975): Ectoparasitic nematodes of the genus Xiphinema Cobb 1913 in orchards in Czechoslovakia. Sborník ÚVTI - Zahradnictví, 2: 79-86

ETTEMA, C. H., Bongers, T. (1993): Characterization of nematode colonization and succession in disturbed soil using the Maturity Index. Biol. Fertil. Soils, 16: $79-85$ Ferris, H., VenetTe, R. C., LAU, S. S. (1996) : Dynamics of nematode communities in tomatoes grown in conventional and organic farming systems, and their impact on soil fertility. Appl. Soil Ecol., 3: $161-175$

Ferris, H., Bongers, T., DE GoEde, R. G. M. (2001) : A framework for soil food web diagnostics: extension of the nematode faunal analysis concept. Appl. Soil Ecol., 18: 13 - 29. DOI: 10.1016/S0929-1393(01)00152-4

Fiscus D. A., NeHER D. A. (2002): Distinguishing sensitivity of free-living soil nematode genera to physical and chemical disturbances. Ecol. Appl., 12: 565 - 575

Griffin, G. D., AsAY, K. H., Horton, W. H. (1996): Factors affecting population trends of plant-parasitic nematodes on rangeland grasses. J. Nematol., 28: $107-114$. DOI: $10.1163 / 156854103773040808$

Griffiths, B. S., NeILsON, R., BengOUgh, A. G. (2003): Soil factors determined nematode community composition in a 2 year pot experiment. Nematology, 5: $889-897$

HAY, F. S., Close, R. C. (1992): Xiphinema diversicaudatum (Micoletzky, 1927) Thorne, 1939 in commercial hop (Humulus lupulus L.) gardens in New Zealand implication for the spread of Arabic Mozaic Virus. New Zeal. J. Crop. Hort., 20: 367 - 370

Hay, F., Pethybridge, S. (2003): Plant-parasitic nematodes associated with hop production in Tasmania Australia. J. Phytopathol., 151: 369 - 375

HÁNĚL, L. (1994): Structure and dynamics of soil nematode community in beat and potato fields. Biologia, Bratislava. 49: 153 - 159

HÁNĚL L. (1997): Vertical distribution of soil nematode diversity and abundance in a Central European oak forest. Acta Soc. Zool. Bohem., 61: $97-112$

HÁNĚL, L. (2003): Soil nematodes in cambisol agroecosystems of the Czech Republic. Biologia (Bratislava), 58: $205-216$

HÁNĚL, L. (2008): Nematode assemblages indicate soil restoration on colliery spoils afforested by planting different tree species and by natural succesion. Appl. Soil Ecol., 40: 86 - 99. DOI: 10.1016/j.apsoil.2008.03.007
HÁNĚL, L. (2010): An outline of soil nematode succession on abandoned fields in South Bohemia. Appl. Soil Ecol., 46: 355 - 371. DOI: 10.1016/j.apsoil.2010.10.005

HÁNĚL, L., ČEREVKovÁ, A. (2006): Diversity of soil nematodes in meadows of the White Carpathians. Helminthologia. 43: 109 - 116. DOI 10.2478/s11687-0060021-1

HÁNĚL, L., ČEREVKOVÁ, A. (2010): Species and genera of soil nematodes in forest ecosystems of the Vihorlat Protecte Landscape Area, Slovakia. Helminthologia, 47: 123 135. DOI: $10.2478 / \mathrm{s} 11687-010-0019-6$

Hartley S. E., Nelson K., Gorman M. (1995): The effect of fertilizer and shading on plant chemical composition and palatability to Orkney voles, Microtus arvalis orcadensis. Oikos, 72: 79-87. DOI: 10.2307/3546041

HOGER, C.H. (1988): Plant parasitic nematodes in Swiss hop yeards. Hopfenrundschau, 39: 127 - 130

Hooper, D. J., Cowland, J. A. (1986): Fungal hosts for the chrysanthemum nematode, Aphelenchoides ritzemabosi. Plant Pathol., 35: 128 - 129

Hooper, D. J., IBrahim, S. K. (1994): Aphelenchoides nechaleos n.sp. and A. paranechaelos n.sp. (Nematoda: Aphelenchoididae) from rice plants. Funnd. Appl. Nematol., 17: $153-160$

HrabĚ, S. (1954): Key to animals of Czechoslovakia. Part I. Praha, 538 pp. (In Czech)

JAndÁk, J., Pokorný, E., Prax, A. (2001): Pedology. Brno, Mendelova zemédělská a lesnická univerzita, 140 pp. (In Czech)

Kumari, S., Polák, J., ChoutKa, R. (2005): Plant-parasitic nematodes of the genus Xiphinema (Nematoda: Longidoridae) in the vineyards of the Czech Republic. Nematology, 7: 81 - 93. DOI: 10.1163/1568541054192117 KUMARI, S. (2006): Xiphinema simile (Nematoda: Longidoridae) in the Czech Republic and a note on other Xiphinema species. Helminthologia, 43: 43 - 50. DOI: 10.24 78/s11687-006-0009-X

LIŠKOVÁ, M., ČEREVKOVÁ, A. (2005): Nematode communities of river banks and adjacent meadows in the Slovak Republic. Helminthologia, 42, 223 - 232

LišKovÁ, M., Vovlas, N., SASANElli, N. (2004): Criconematidae (Nematoda) in the Slovak Republic. Helminthologia, 41: $161-170$

LIŠKOVÁ M., RENČO M. (2007): Communities of free living and plant parasitic nematodes in hop gardens in Slovakia. Helminthologia, 44: 80 - 86. DOI 10.2478/s11687007-0008-6

Losos B., GuličKa J., LelláK J., PelikÁN J. (1984): Animal Ecology. Státní pedagogické nakladatelství Praha, 316 pp. (In Czech)

LÓPEZ-FANDO, C., Bello, A. (1995): Variability in soil nematode populations due to tillage and crop rotation in semi-arid Mediterranean agrosystems. Soil Till. Res., 36, 59-72. DOI: 10.1016/0167-1987(95)00496-3

MAGGENTI, A. R. (1962): Hot water treatment of hop rhizomes for nematode control. California agriculture, 16: 11 $-12$

Malan, A. P., Pieterse, W., Britis, G. (1991): Plant-para- 
sitic nematodes associated with hops (Humulus lupulus L.) in south Africa. Phytopathologica, 23: $173-175$

MatTson, W. J. (1980): Herbivory in relation to plant nitrogen content. Annu. Rev. Ecol. Syst., 11: $119-161$

Mende, N. Von, MCNAmara, D. G. (1995): Biology of the hop cyst nematode Heterodera humuli I. Life cycle and survival. Ann. Appl. Biol., 126: 505 - 516

MCNAmARA, D. G., EPPLER, A. (1989): The Longidoridae occuring in the German hop-growing regions. Proceedings Int. Workshop on Hop Virus Diseases Rauischholzhausen 1988, EPPLER A. (Ed) Deutsche Phytomedizinische Gesellschaft: $195-197$

MCSORLEY, R. (1997): Relation of crop and rainfall to soil nematode community structure in perennial agroecosystems. Appl. Soil Ecol., 6: 147 - 159

MCSORLEY, R., DiCKSON, D. W. (1997): Vertical distribution of plant parasitic nematodes in sandy soil under Soybean. J. Nematol., 22 (1): $90-96$

NeHER D. A., CAMPBEll C. L. (1994): Nematode communities and microbial biomass in soils with annual and perennial crops. Appl. Soil Ecol., 1: $17-28$

NumBER, K. (1958): Uber die Beteiligung des HopfenZystenälchens (H. humuli Fil.) an Misswuchsercheinungen des Hopfens im Bodenseegebiet. Nachrichtenbl. $d$. Deutsch. Pflanzenschutzdienstes, 10 (7): 103 - 104 (In German)

OlfF, H., Berendse, F., De Viseer, W. (1994): Changes in nitrogen mineralization, tissue nutrient concentration and biomass compartmentation after cessation of fertilizer application to mown grassland. J. Ecol., 82: $611-620$

OU W., LIANG W., JiANG Y., Li Q., WEN D. (2005): Vertical distribution of soil nematodes under different land use types in an aquic brown soil. Pedobiologia, 49: 139-148. DOI: 10.1016/j.pedobi.2004.10.001

Pen-Mouratov S., RakhimbaeV M., Steinberger Y. (2003): Seasonal and spatial variation in nematode communities in a Negev Desert ecosystem. J. Nematol., 35: $157-166$

POLÁK, J. (1994): Distribution of apple mosaic virus in hop gardens of the Czech Republic. Ochrana Rostlin, 30: 85 - 89 RENČO, M. (2002): Seasonal dynamics of plant parasitic and free living nematodes in sugar beet, cereals and lucerne in East Slovakia. Helminthologia, 39: 51 - 57

RENČO, M. (2003): The Communities of nematodes in agroecosystems of sugar beet, cereals and lucerne in Eastern Slovakia. Helminthologia, 40: 55 - 58

RenČO, M., D’AdDabbo T., SASAnelli N., PAPAJOVÁ I. (2007): The effect of five compost of different origin on the survival and reproduction of Globodera rostochiensis. Nematology, 9: 537 - 243. DOI: 10.1163/15685410778148 7260

RENČO, M., VALOCKÁ, B. (2002): Communities of soil and plant nematodes in sugar beet growing areas of the Slovak Republic. Biológia (Bratislava), 57: 569 - 573

RENČO M., LIŠKOVÁ M., ČEREVKOVÁ A. (2010a): Seasonal fluctuations of the nematode communities in a hop garden soil. Helminthologia , 47: 115 - 122. DOI: 10.2478/s11687010-0018-7
RenČo, M., SAsanelli, N., Šalamún, P. (2009): The effect of two kompost soil amendments, based on municipal green and penicillin production wastes, on plant parasitic nematodes. Helminthologia, 46: 190 - 197. DOI: 10.2478/s11687-009-0035-6

RenČO, M., SASANElli, N., D’AdDABBo, T., PAPAJOVÁ, I. (2010b): Soil nematode community changes associated with compost amendments. Nematology, 12: $681-692$. DOI: $10.1163 / 138855409 X 12584413195491$

ŠÁLY A. (1973): Vertical and seasonal distribution of nematodes in the soil of the Báb forest. Biológia (Bratislava), 28: 91 - 104. (In Slovak with English abstract)

ŠÁLY, A., Kř́í̌, J. (1961): Hop cyst nematode - pest of hop. Chmelařství, 34: 43. (In Czech)

ŠEDIVÝ, J. (1963): Remarks on the occurrence of hop cyst nematode (Heterodera humuli Filipjev) in Czechoslovakia. Zoologické listy, 12 (3): 185 - 188. (In Czech)

DE GRISSE, A. T. (1969): Redescription ou modification de quelques techniques utilisés dans l'étude des nématodes phytoparasitaires. Meded. Rijksfakulteit Landbouwwetenschappen Gent, 34: 351 - 369

Shannon, C. E., WeAVER, W. (1949): The mathematical theory of communication. University of Illinois, Urbana, Illinois, USA

SIMON, L. (1958): Nematologische Untersuchungen an Hopfen II. Zur Morphologie und Biologie von Heterodera humuli Filipjev. Nematologica, 3 (4): 269 - 273. (In German)

Sohlenius, B., BoströM, S. (2001): Annual and long term fluctuations of the nematode fauna in a Swedish Scots pine forest soil. Pedobiologia, 45: 408 - 429. DOI: 10.1078/0031-4056-00096

SOHLENIUS, B., SANDOR, A., (1987): Vertical distribution of nematodes in arable soil under grass (Festuca pratensis) and barley (Hordeum vulgare). Biol.Fertil. Soils, 3 (1 - 2): $19-25$

Solovyeva, G. I., Vasilyeva, A. P., Gruzdeva, L. I. (1976): Svobodnozhivuschie i fytoparaziticheskie nematody severo-zapada SSSR (Free-living and plant parasitic nematodes of north-west USSR). Nauka, Leningrad: 106 pp.

THOMAS, P. R. (1970): Host status of some plants for Xiphinema diversicaudatum (Micol.) and their susceptibility to virus transmited by this species. Ann. Appl. Biol., 65: $169-178$

Valdez, R. B., McNamara, D. G., Ormerod, P. J., PITCHER, R. S., Thresh, J. M. (1974): Transmission of the hop strain of arabis mosaic virus by Xiphinema diversicaudatum. Ann. Appl. Biol. 76: 113 - 122

VAlockÁ, B., SAbOvÁ, M., RenČO, M. (2001): Soil and plant nematode communities of two types of ecosystems. Helminthologia, 38: 105 - 109

Verschoor, B. C., De Goede, R. G. M., DE Vries, F. W., BRUSSAARD, L. (2001): Changes in the composition of the plant-feeding nematode comunity in grassland after cessation of fertiliser application. Appl. Soil Ecol., 17: 1 - 17. DOI: 10.1016/S0929-1393(00)00135-9

WASILEWSKA, L. (1965): Ditylenchus medicaginis sp. n., a new parasitic nematode from Poland (Nematoda, Ty- 
lenchidae). Bulletin de l'Académie polonaise des sciences. Série des sciences biologiques., 13: 167 - 70

WASILEWSKA L. (1979): The structure and function of soil nematode communities in natural ecosystems and agrocenoses. Pol. Ecol. Stud., 5: $97-145$

WASILEWSKA L. (1997): Soil invertebrates as bioindicators, with special reference to soil-inhabiting nematodes. Russ. J. Nematol., 5: $113-126$

WASILEWSKA, L. (2004): Nematofauna of the shelterbelts in the agricultural landscape. Pol. J. Ecol., 52: 99 - 113 WASILEWSKA, L. (2006): Changes in the structure of the soil nematode community over long-term secondary grassland succession in drained fen peat. Appl. Soil Ecol., 32: 165 - 179. DOI: 10.1016/j.apsoil.2005.07.003

YeAtes G. W. (1980): Populations of nematode genera in soils under pasture: III. Vertical distribution at eleven sites. N. Zeal. J. Agric. Res., 23: $117-128$

YEATES, G. W. (1986): Stylet and body lenghts as niche dimensions in plant-parasitic nematodes. Zool. Anz., 216: $327-337$

RECEIVED DECEMBER 30, 2010
YeAtes, G. W. (1987): How plants affect nematodes. $A d v$. Ecol. Res., 17: $61-113$

Yeates, G. W., Bongers, T., DE Goede, R. G. M., FreckMAN, D. W., GEORGIEVA, S. S. (1993): Feeding habits in soil nematoe families and genera - an outline for soil ecologists. J. Nemat., 25: $315-331$

YEATES G. W. (1994): Modification and qualification of the nematode maturity index. Pedobiologia. 38: 97 - 101

Yeates, G. W., Dando, J. L., Sheperd, T. G. (2002): Pressure plate studies to determine how moisture attects access of bacterial-feeding nematodes to food in soil. Eur. J. Soil Sci., 53: 355 - 365. DOI: 10.1046/j.1365-2389.20 02.00466.x

YEATES G. W. (2003): Nematodes as soil indicators: functional and biodiversity aspects. Biol. Fertil. Soils., 37: 199 - 210. DOI: 10.1007/s00374-003-0586-5

ZOUHAR, M., RYŠÁNEK, P., TESAŘOVÁ, B. (2003). Occurrence of the Root-Knot Nematode Meloidogyne hapla in the Czech Republic. Plant Disease., 87: 98

ACCEPTED FEBRUARY 1, 2011 